\title{
Nutritional and morphophysiological responses of soybean to micronutrient fertilization in soil
}

\author{
Rubens Ribeiro da Silva*, Larissa Urzêdo Rodrigues, Rodrigo Ribeiro Fidélis, Álvaro José Gomes de Faria \\ and Vitor L. Nascimento
}

Federal University of Tocantins, Gurupi, TO, Brazil.

*Author for correspondence: rrs2002@uft.edu.br

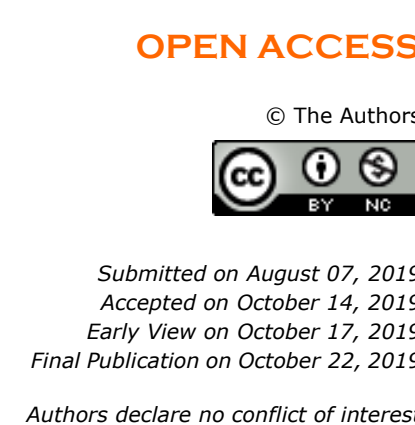

KEYWORDS: Glycine max L. Low solubility fertilize Plant nutrition Photosynthesis

\section{ABSTRACT}

Micronutrient fertilization is essential to meet the nutritional deficiency of plants, providing the full development of crops. The aim of this work was to evaluate the effects of fertilization with micronutrients applied in the soil on the nutrition and morphology of soybean plants. The experimental design was completely randomized, with four replications. The treatments consisted of fertilization with micronutrients applied to soil to reach three levels of availability of B: low ( $<0.15 \mathrm{mg} \mathrm{dm}^{-3}$ - control), good $\left(0.61 \mathrm{mg} \mathrm{dm}^{-3}\right)$ and high $\left(>0.90 \mathrm{mg} \mathrm{dm}^{-3}\right)$. For this, the following values were applied: 0.00 (control), 56.67 and $211.11 \mathrm{~kg} \mathrm{ha}^{-1}$ of the fertilizer containing $1.8 \% \mathrm{~B}, 0.85 \% \mathrm{Cu}, 2 \% \mathrm{Mn}$ and $9 \% \mathrm{Zn}$. Fertilization with the good and high treatments did not affect the uptake of $\mathrm{B}$, but increased the $\mathrm{Cu}$ and $\mathrm{Mn}$ content, and reduced the $\mathrm{Zn}$ content in the plants. Higher plants with greater leaf expansion were observed in the high treatment, however, this did not influence the soybean grain yield. In the control, the physiological activity revealed smaller $\mathrm{A}$, whereas gs and $\mathrm{Ci}$ were more effective; reverse effect was observed with high treatment. Fertilization with micronutrients in the soil affects the nutritional status and the photosynthetic activity of the plants due to the imbalance in the concentrations of $\mathrm{B}, \mathrm{Cu}, \mathrm{Mn}$ and $\mathrm{Zn}$ supplied with the fertilizer, reflecting in the absence of gains in the production of soybean grains.

\section{Highlighted Conclusions}

1. Fertilization with micronutrients in the soil using as criterion the reach of three levels of availability of $B$ does not increase the production of biomass and grains, despite ensuring foliar contents of $B(\bar{Y}=40.40)$ and $\mathrm{Cu}(\bar{Y}=23.06)$ suitable for soybean cultivation in the Cerrado.

2. The inequity in the concentrations of $\mathrm{B}, \mathrm{Cu}, \mathrm{Mn}$ and $\mathrm{Zn}$ supplied with fertilizer affects the physiological performance of soybean plants.

\section{INTRODUCTION}

The success of soybeans production in Brazil depends on a successful fertility program that includes all the essential nutrients for the growth and development of this oilseed (Gaspar et al. 2018). Despite the advances in micronutrient research - driven in large part by the success of fertilization with macronutrients such as nitrogen $(N)$, phosphorus (P) and potassium (K) (Burns 2017); the supply of boron (B), copper (Cu), manganese (Mn) and zinc $(\mathrm{Zn})$ needs to be better understood, given the importance of these nutrients in biochemical and physiological processes vital to plant production (Hänsch and Mendel 2009, Marschner 2012).

Recent studies have shown that soil fertilization with micronutrients increases the levels of these elements in cultivated areas (Barbosa et al. 2016), revealing that the reach of high soybean yields (between 3,328 and 5,583 $\mathrm{kg} \mathrm{ha}^{-1}$ ) is conditioned by the absorption of $\mathrm{B}, \mathrm{Cu}, \mathrm{Mn}$ and $\mathrm{Zn}$ in the order of 24.3 to $42.7,5.3$ to $9.4,57.2$ to 113 and 24.5 to $56.8 \mathrm{mg} \mathrm{kg}^{-1}$ of biomass (Urano et al. 2007, Enderson et al. 2015). In addition, the effects of micronutrient fertilization on the photosynthetic activity of plants have been widely reported (Wang et al. 2009, llyas et al. 2015, Tavallali 2017, Flores et al. 2018a).

Since fertilization costs strongly impact the soybean production system in the Cerrado, representing up to $47.45 \%$ of the total invested per hectare (Richetti and Garcia 2017); that the results of the research show a limitation of wide applicability (Gaspar et al. 2018) and that diagnostic tools in assessing the availability of 
micronutrients in the plant imply unnecessary fertilization in some regions (Enderson et al. 2015); the knowledge of the effects promoted by soil fertilization with sources of low solubility based on the morphophysiological aspects can help in the nutritional management of the soybean crop, contributing to the improvement of crop growth and yield. The aim of this study was to evaluate the effects of fertilization with micronutrients in the form of oxides applied in the soil on the nutrition and morphophysiology of soybean plants.

\section{MATERIAL AND METHODS}

The work was carried out in the experimental area of the Universidade Federal do Tocantins (UFT) campus Gurupi $\left(11^{\circ} 43^{\prime} 45^{\prime \prime} \mathrm{S}\right.$ and $49^{\circ} 04^{\prime} 07^{\prime \prime} \mathrm{W}$, altitude $\left.278 \mathrm{~m}\right)$. The region is classified as Brazilian Cerrado, with annual average temperature of $29.5^{\circ} \mathrm{C}$ and average rainfall of $1,804 \mathrm{~mm}$, being a rainy summer and a dry winter (SEPLAN 2012).

A Red-Yellow Latosol collected from the $20 \mathrm{~cm}$ layer was used in the experiment, previously discharged and sieved with a mesh of $2.75 \mathrm{~mm}$ and incubated for acidity correction using a 2.5:1 mixture of calcium carbonate $\left(\mathrm{CaCO}_{3}\right)$ and magnesium $\left(\mathrm{MgCO}_{3}\right)$, whose applied dose was determined in previous assays to reach $\mathrm{pH} 6.0$ (Santos et al. 2013a). The chemical and physical analysis of the soil after the application of the carbonates is in Table 1.

Table 1. Chemical attributes and physical properties of a Red-Yellow Oxisol used

\begin{tabular}{|c|c|c|c|c|c|c|}
\hline \multirow[t]{2}{*}{$\mathrm{pH}\left(\mathrm{H}_{2} \mathrm{O}\right)$} & $\mathrm{Al}^{3+}$ & $\mathrm{H}+\mathrm{Al}$ & C.E.C. $\left.{ }^{(1)}\right)$ & $\mathrm{m}^{(2)}$ & $\mathrm{V}^{(3)}$ & O.M. ${ }^{(4)}$ \\
\hline & \multicolumn{4}{|c|}{. } & \multicolumn{2}{|c|}{ 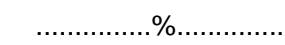 } \\
\hline 6.20 & 0.00 & 2.20 & 5.14 & 0.00 & 57.00 & 1.80 \\
\hline \multirow[t]{2}{*}{$\mathrm{Ca}^{2+}$} & $\mathrm{Mg}^{2+}$ & $\mathrm{K}^{+}$ & S.B. ${ }^{(5)}$ & $\mathrm{P}_{\text {Meh }}$ & $\mathrm{S}$ & $\mathrm{B}$ \\
\hline & \multicolumn{3}{|c|}{...........cmol $\mathrm{Cdm}^{-3} \ldots \ldots$} & \multicolumn{3}{|c|}{$\ldots \mathrm{mg} \mathrm{dm}^{-3} .}$. \\
\hline 2.10 & 0.70 & 0.14 & 2.94 & 10.50 & 6.00 & 0.10 \\
\hline \multirow[t]{2}{*}{$\mathrm{Cu}$} & $\mathrm{Fe}$ & $\mathrm{Mn}$ & $\mathrm{Zn}$ & Sand & Silt & Clay \\
\hline & ............ & & & & $\ldots \% \ldots$ & \\
\hline 0.80 & 36.00 & 1.70 & 8.70 & 65.00 & 5.00 & 30.00 \\
\hline
\end{tabular}

The experimental units were composed of polyethylene bags $(30 \times 45 \mathrm{~cm})$ filled with $7.0 \mathrm{dm}^{3}$ of soil. Base fertilization (single superphosphate $-18 \% \mathrm{P}_{2} \mathrm{O}_{5}$ and potassium chloride $-60 \% \mathrm{~K}_{2} \mathrm{O}$ ) was carried out, with doses of each fertilizer calculated to reach levels classified as good availability for soybean cultivation, according Ribeiro et al. (1999).

The experimental design was completely randomized, with four replications. The treatments consisted of fertilization with micronutrients applied in the soil, adopting as criterion the reach of three levels of $B$ availability: low $\left(<0.15 \mathrm{mg} \mathrm{dm}^{-3}\right.$ - control), good $\left(0.61 \mathrm{mg} \mathrm{dm}^{-3}\right)$ and high $\left(>0.90 \mathrm{mg} \mathrm{dm}^{-3}\right)$. For this, the following values were applied: 0.00 (control), 56.67 and $211.11 \mathrm{~kg} \mathrm{ha}^{-1}$ of the FTE BR12 fertilizer $(1.8 \% \mathrm{~B}, 0.85 \% \mathrm{Cu}, 2 \% \mathrm{Mn}$ and $9 \%$ $\mathrm{Zn})$. The concentrations of $\mathrm{B}, \mathrm{Cu}, \mathrm{Mn}$ and $\mathrm{Zn}$ in each treatment are shown in Table 2.

Table 2. Concentrations of $\mathrm{B}, \mathrm{Cu}, \mathrm{Mn}$ and $\mathrm{Zn}$ for each treatment with the fertilizer applied in the soil.

\begin{tabular}{cccccc}
\hline \multirow{2}{*}{ Treatment } & \multirow{2}{*}{$\begin{array}{c}\text { Fertilizer concentration } \\
\left(\mathrm{kg} \mathrm{ha}^{-1}\right)\end{array}$} & \multicolumn{4}{c}{$\begin{array}{c}\text { Micronutrient concentration applied } \\
\left(\mathrm{mg} \mathrm{dm}^{-3}\right)\end{array}$} \\
\cline { 3 - 6 } & & $\mathrm{B}$ & $\mathrm{Cu}$ & $\mathrm{Mn}$ & $\mathrm{Zn}$ \\
\hline Low & 0.00 & - & - & - & - \\
Good & 56.67 & 0.51 & 0.24 & 0.57 & 2.55 \\
High & 211.11 & 1.90 & 0.90 & 2.11 & 9.50 \\
\hline
\end{tabular}

Six seeds of soybean cv. M8349 IPRO were treated chemically with insecticide Fipronil (i.a.) and fungicide Thiophanate-methyl + Fluazinam (i.a.) and inoculated with Bradyrhizobium japonicum. At 15 days after sowing, thinning was done leaving three plants per pot. The plants were drip irrigated three times a day by semi-automated system. When necessary, phytosanitary management was performed with insecticide Acetamipride (i.a.) and fungicides Trifloxystrobin + Prothioconazole (i.a.).

To evaluate the effect of treatments on shoot morphophysiology and nutritional status of soybean, leaf samples were collected when $50 \%$ of the plants were in the R2 (full flowering) stage and were then sent to the laboratory to determine: plant height $(\mathrm{cm})$; stem diameter $(\mathrm{mm})$; number of branches per plant (un);number of flowers per plants (un); dry weight of shoot, leaves and $\operatorname{discs}(\mathrm{g})$ : the plants, the leaves, without petiole, and, with the aid of a 
perforator, 12 discs were removed from the central part of the leaves, were conditioned in paper bags and dried in a forced circulation oven at $65^{\circ} \mathrm{C}$ for $72 \mathrm{~h}$. After this period, they were weighed in a precision scale $(0.00 \mathrm{~g})$; leaf area $\left(\mathrm{LA}-\mathrm{cm}^{2}\right)$ : the leaf area of each plant was calculated according to Equation 1:

$$
\mathrm{LA}=\frac{(\mathrm{ND} \times \mathrm{AxDWL})}{\mathrm{DWD}}
$$

Equation 1

where in: ND: number of discs; DA: disc's area, in $\mathrm{cm}^{2}$; DWL: dry weight of leaves, in $\mathrm{g}^{-1}$; and DWD: dry weight of the discs, in $\mathrm{g}^{-1}$.

Specific leaf area (SLA $-\mathrm{cm}^{2} \mathrm{~g}^{-1}$ ) was determined according to Equation 2:

$$
\text { SLA }=\frac{\text { TLA }}{\text { DWL }}
$$

Equation 2

Foliar contents of $B$ (mg kg-1 biomass): adapted from Carmo et al. (2000), using $0.1 \mathrm{~mol} \mathrm{~L}^{-1} \mathrm{HCl}$ to extract the

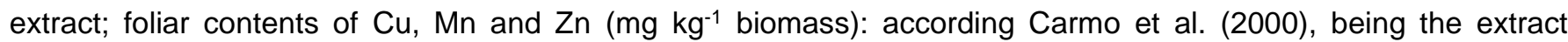
obtained by perchloric nitric digestion and the element determined by atomic absorption spectroscopy.

The photosynthetic activity of the soybean plants was analyzed by means of reading fully developed leaves, from each plant ten times, using an Infrared Gas Analyzer - IRGA, LCiSD ADC system ${ }^{\circledR}$, from 9 to 12 o'clock on days with clear sky, in order to maintain the homogeneous environmental conditions during the evaluations. The photosynthetic pigments were quantified by readings at the center of the leaf using a ClorofiLOG® chlorophyll meter model CFL 1030 Falker, which provides results in dimensionless units, $\mathrm{FCl}$ values (Falker Chlorophyll Index). The physiological parameters obtained were : total chlorophyll (FCl); net $\mathrm{CO}_{2}$ assimilation rate $(A-\mu \mathrm{mol}$ $\left.\mathrm{CO}_{2} \mathrm{~m}^{-2} \mathrm{~s}^{-1}\right)$; stomatal conductance $\left(g s-\mathrm{mmol} \mathrm{H}_{2} \mathrm{O} \mathrm{m} \mathrm{m}^{-2} \mathrm{~s}^{-1}\right)$; transpiration rate $\left(E-\mathrm{mmol} \mathrm{H}_{2} \mathrm{O} \mathrm{m}^{-2} \mathrm{~s}^{-1}\right)$; internal $\mathrm{CO}_{2}$ concentration ( $\mathrm{Ci}-\mu \mathrm{mol} \mathrm{CO} \mathrm{mol}^{-1}$ air); water use efficiency (WUE - $\mu \mathrm{mol} \mathrm{CO}_{2} \mathrm{~mol}^{-1} \mathrm{H}_{2} \mathrm{O}$ ).

At the end of the crop cycle and at the time of harvest, the results from the average of two plants per pot evaluated the yield characteristics of soybean: number of pods per plant (un); number of grains per pod (un); number of grains per plant (un); grain weight per plant (g); hundred grains weight (g).

Data were submitted to analysis of variance with the averages evaluated by the Tukey test at $5 \%$ of probability, using the software SISVAR 5.6 (Ferreira 2010).

\section{RESULTS}

Table 3 presents the summary of the analysis of variance for the morphophysiological characteristics, nutritional status and yield components of soybean plants submitted to fertilization with micronutrients incorporated in the soil.

Micronutrient fertilization in the treatments of good and high availability of micronutrients promoted significant effects $(p \leq 0.05)$ on the morphological development of soybean plants, increasing up to $19 \%$ in plant height, $18 \%$ in number of branches per plant, $34 \%$ in leaf area and $15 \%$ in specific leaf area in relation to control (low availability of micronutrients) (Table 4). On the other hand, stem diameter and dry weight of shoot was not influenced by treatments.

The photosynthetic activity of the plants was influenced $(p \leq 0.05)$ by micronutrient fertilization, with a slight increase in total chlorophyll content $(11 \%)$ and substantial improvement in WUE $(239 \%)$ of plants cultivated in the treatment with good availability of micronutrients, whereas $A$ was $15 \%$ better in the treatment with high levels of micronutrients (Table 5). Furthermore, the increase of micronutrient concentrations in the treatments with good and high levels affected the other physiological parameters evaluated, reducing in three times the value of $g s$ and five times the value of $E$, but maintaining almost unchanged the $C i$, in comparison with the higher values observed in the control.

The nutritional status of soybean plants was significantly influenced $(p \leq 0.05)$ by fertilization with micronutrients applied to the soil, except for the B content, maintained in the average of $40.4 \mathrm{mg} \mathrm{kg}^{-1}$ of biomass (Table 6). Generally, treatments with good and high levels of micronutrients increased about 2.5 times the $\mathrm{Cu}$ and $\mathrm{Mn}$ content, while reducing the $\mathrm{Zn}$ content by $46 \%$ compared to the control.

Micronutrients applied in soil significantly affected $(p \leq 0.05)$ soybean yield components, where the increase of concentrations in the treatments with good and high availability increased, on average, $23 \%$ number of flowers per plants (Table 7). For number of pods per plant and number of grains per plant the best results did not differ between the control and the treatment with high levels of micronutrients, presenting average gains in the order of $20 \%$ and $9 \%$ in relation to the treatment with good levels of micronutrient. 
Table 3. Analysis of variance of the traits plant height (PH), stem diameter (SD), number of branches per plant (BP), dry weight of shoot (DWS), leaf area (LA), specific leaf area (SLA), total chlorophyll $(\mathrm{Chl})$, net $\mathrm{CO}_{2}$ assimilation rate $(A)$, stomatal conductance $(g s)$, transpiration rate $(E)$, internal $\mathrm{CO}_{2}$ concentration $(C i)$, water use efficiency (WUE), foliar contents of $\mathrm{B}, \mathrm{Cu}, \mathrm{Mn}$ and $\mathrm{Zn}$, number of flowers per plants (FP), number of pods per plant (PP), number of grains per pod (GPo), number of grains per plant (GPI), grain weight per plant (GW), hundred grains weight (HG) of soybean plants submitted to soil fertilization with micronutrients.

\begin{tabular}{ccccc}
\hline \multirow{2}{*}{ Traits } & Degrees of freedom & Residual & Average & \multirow{2}{*}{ C.V. (\%) } \\
\cline { 2 - 4 } & 2 & 9 & 38.69 & 5.06 \\
PH & $47.63^{*}$ & 3.84 & 3.80 & 7.57 \\
SD & $0.01^{\text {ns }}$ & 0.08 & 10.37 & 7.40 \\
BP & $3.24^{*}$ & 0.59 & 4.38 & 8.21 \\
DWS & $0.38^{\text {ns }}$ & 0.13 & 717.04 & 8.96 \\
LA & $43,129.00^{* *}$ & $4,130.00$ & 233.85 & 0.81 \\
SLA & $1,221.11^{* *}$ & 3.59 & 34.45 & 3.13 \\
Chl & $13.28^{* *}$ & 1.16 & 9.62 & 4.84 \\
A & $15.69^{* *}$ & 0.22 & 0.38 & 13.49 \\
gs & $0.133^{* *}$ & 0.00 & 5.48 & 8.37 \\
$E$ & $45.70^{* *}$ & 0.21 & 321.42 & 1.29 \\
Ci & $432.81^{* *}$ & 17.26 & 2.41 & 7.76 \\
WUE & $9.17^{* *}$ & 0.04 & 40.40 & 6.49 \\
B & $11.32^{\text {ns }}$ & 6.88 & 23.08 & 4.02 \\
Cu & $387.58^{* *}$ & 0.86 & 6.10 & 8.59 \\
Mn & $27.15^{* *}$ & 0.27 & 15.88 & 3.77 \\
Zn & $117.30^{* *}$ & 0.36 & 47.67 & 7.33 \\
FP & $114.78^{* *}$ & 12.2 & 11.49 & 6.31 \\
PP & $5.99^{* *}$ & 0.52 & 2.24 & 6.73 \\
GPo & $0.07^{\text {ns }}$ & 0.02 & 25.55 & 2.88 \\
GPI & $6.79^{* *}$ & 0.54 & 4.61 & 4.50 \\
GW & $0.06^{\text {ns }}$ & 0.04 & 17.98 & 9.91 \\
HG & $5.49^{\text {ns }}$ & 3.17 & &
\end{tabular}

Table 4. Plant height, stem diameter, number of branches per plant, dry weight of shoot, leaf area and specific leaf area of soybean plants submitted to soil fertilization with micronutrients.

\begin{tabular}{cccc}
\hline Morphological traits & \multicolumn{3}{c}{ Treatments } \\
\cline { 2 - 4 } & Low & Good & High \\
\hline Plant height (cm) & $35.38 \mathrm{~b}$ & $38.44 \mathrm{ab}$ & $42.26 \mathrm{a}$ \\
Stem diameter (mm) & 3.83 & 3.74 & 3.82 \\
Number of branches per plant (un) & $9.38 \mathrm{~b}$ & $11.13 \mathrm{a}$ & $10.61 \mathrm{ab}$ \\
Dry weight of shoot (g) & 4.04 & 4.44 & 4.65 \\
Leaf area $\left(\mathrm{cm}^{2}\right)$ & $607.93 \mathrm{~b}$ & $728.54 \mathrm{ab}$ & $814.64 \mathrm{a}$ \\
Specific leaf area $\left(\mathrm{cm}^{2} \mathrm{~g}^{-1}\right)$ & $219.56 \mathrm{c}$ & $228.66 \mathrm{~b}$ & $253.33 \mathrm{a}$ \\
\hline
\end{tabular}

Means with the same lowercase letters in the row do not differ by the Tukey test at $5 \%$.

Table 5. Total chlorophyll, net $\mathrm{CO}_{2}$ assimilation rate $(A)$, stomatal conductance ( $\left.g s\right)$, transpiration rate $(E)$, internal $\mathrm{CO}_{2}$ concentration $(C I)$, and water use efficiency of soybean plants submitted to soil fertilization with micronutrients.

\begin{tabular}{|c|c|c|c|}
\hline \multirow{2}{*}{ Physiological traits } & \multicolumn{3}{|c|}{ Treatments } \\
\hline & Low & Good & High \\
\hline Total chlorophyll (ICF) & $32.56 \mathrm{~b}$ & $36.19 \mathrm{a}$ & $34.59 a b$ \\
\hline$A\left(\mu \mathrm{mol} \mathrm{CO}_{2} \mathrm{~m}^{-2} \mathrm{~s}^{-1}\right)$ & $9.91 \mathrm{~b}$ & $7.51 \mathrm{c}$ & $11.44 \mathrm{a}$ \\
\hline$g s\left(\mathrm{mmol} \mathrm{H} \mathrm{H}_{2} \mathrm{O} \mathrm{m}^{-2} \mathrm{~s}^{-1}\right)$ & $0.54 \mathrm{a}$ & $0.18 \mathrm{c}$ & $0.42 \mathrm{~b}$ \\
\hline$E\left(\mathrm{mmol} \mathrm{H}_{2} \mathrm{O} \mathrm{m}^{-2} \mathrm{~s}^{-1}\right)$ & $8.54 \mathrm{a}$ & $1.85 \mathrm{c}$ & $6.04 \mathrm{a}$ \\
\hline $\mathrm{Ci}\left(\mu \mathrm{mol} \mathrm{CO} \mathrm{mol}^{-1} \mathrm{ar}\right)$ & $331.17 \mathrm{a}$ & $310.48 c$ & $322.61 \mathrm{~b}$ \\
\hline WUE $\left(\mu \mathrm{mol} \mathrm{CO} \mathrm{mol}^{-1} \mathrm{H}_{2} \mathrm{O}\right)$ & $1.21 \mathrm{c}$ & $4.11 \mathrm{a}$ & $1.90 \mathrm{~b}$ \\
\hline
\end{tabular}


Table 6. Foliar contents of $\mathrm{B}, \mathrm{Cu}, \mathrm{Mn}$ and $\mathrm{Zn}$ of soybean plants submitted to soil fertilization with micronutrients.

\begin{tabular}{cccc}
\hline \multirow{2}{*}{ Nutritional traits } & \multicolumn{3}{c}{ Treatments } \\
\cline { 2 - 4 } & Low & Good & High \\
\hline B (mg kg ${ }^{-1}$ biomass) & 39.10 & 39.80 & 42.30 \\
$\mathrm{Cu}\left(\mathrm{mg} \mathrm{kg}^{-1}\right.$ biomass) & $11.75 \mathrm{~b}$ & $28.00 \mathrm{a}$ & $29.50 \mathrm{a}$ \\
$\mathrm{Mn}\left(\mathrm{mg} \mathrm{kg}^{-1}\right.$ biomass) & $4.23 \mathrm{~b}$ & $5.00 \mathrm{~b}$ & $9.08 \mathrm{a}$ \\
$\mathrm{Zn}\left(\mathrm{mg} \mathrm{kg}^{-1}\right.$ biomass) & $22.06 \mathrm{a}$ & $13.56 \mathrm{~b}$ & $12.00 \mathrm{c}$ \\
\hline
\end{tabular}

Means with the same lowercase letters in the row do not differ by the Tukey test at $5 \%$.

Table 7. Number of flowers per plants, number of pods per plant, number of grains per pod, number of grains per plant, grain weight per plant, and hundred grains weight of soybean plants submitted to soil fertilization with micronutrients.

\begin{tabular}{cccc}
\hline \multirow{2}{*}{ Yield components } & \multicolumn{3}{c}{ Treatments } \\
\cline { 2 - 4 } & Low & Good & High \\
\hline FP (un) & $41.50 \mathrm{~b}$ & $50.33 \mathrm{a}$ & $51.17 \mathrm{a}$ \\
VP (un) & $12.05 \mathrm{a}$ & $10.09 \mathrm{~b}$ & $12.33 \mathrm{a}$ \\
GV (un) & 2.19 & 2.39 & 2.14 \\
GP (un) & $26.27 \mathrm{a}$ & $24.04 \mathrm{~b}$ & $26.33 \mathrm{a}$ \\
MGP (g) & 4.71 & 4.66 & 4.47 \\
M100 (g) & 18.80 & 18.49 & 16.64 \\
\hline
\end{tabular}

\section{DISCUSSION}

In this study using oxides as a source of micronutrientes, the best observed results for the developmental characteristics of the culture may be related to the accumulation of $B\left(\bar{Y}=40.40 \mathrm{mg} \mathrm{kg}^{-1}\right)$ and $\mathrm{Cu}\left(\bar{Y}=23.08 \mathrm{mg} \mathrm{kg}^{-1}\right)$ foliar, whose average contents are considered enough for the full development of the culture in the Cerrado (Galrão 2004). In this way, the reflexes of adequate nutrition of B manifested in the vegetative and reproductive growth of the plants, as observed for plant height, leaf area, number of flowers per plants, number of pods per plant and number of grains per plant (Tables 4 and 7), with highlight to the role of this micronutrient in the synthesis and elongation of cell wall and pollen tube growth (Dechen and Nachtigall 2006, Hänsch and Mendel 2009).

The acceptable accumulation of $\mathrm{Cu}$ in soybean leaves reveals the presence of a sophisticated mechanism that maintains its capture, mobilization and storage (Clemens 2001), even in the control (low soil availability - Table 1). According Ando et al. (2013), the absorption and transport of $\mathrm{Cu}$ is done through the roots to the xylem, from where the $\mathrm{Cu}$ is translocated to the shoot through different transporters in the plasma membrane, suggesting the dynamic regulation of the intracellular concentrations in response to the physiological demand of plants (Adress et al. 2015, Vatansever et al. 2016a). However, similarly to results demonstrated in this work, Barbosa et al. (2016) observed that the use of $132.32 \mathrm{~kg} \mathrm{ha}^{-1}$ of a source of micronutrients (mixture of salts, sulphates and oxides - sulphate) did not promote any effect on the leaf content of $\mathrm{Cu}$ of soybean, although increasing the availability of the element in the soil. For some authors, this reinforces the different levels of $\mathrm{Cu}$ requirement between cultivars for the normal development of plants (Mantovi et al. 2003).

Regarding the physiological traits, this has been widely reported photosynthetic responses to nutrient supply (Warren 2004, Wang et al. 2009, Tavallali 2017). It is known that micronutrients act in the process of photosynthesis in different ways, in synthesis: participating in the metabolism of carbohydrates (B), fixing carbon and forming enzymes ( $\mathrm{Fe}$ and $\mathrm{Mn}$ ), integrating the electron transport chain $(\mathrm{Cu})$ and acting as an activator of photosynthetic enzymes of the oxidase class (Zn) (Cakmak and Römheld 1997, Santos et al. 2013b). In this sense, the photosynthetic activity of the plants evaluated in R2 presented the best total chlorophyll index and WUE, especially when the soil was fertilized with good availability of micronutrients (Table 5). Considering that both $B$ deficiency and excess affect root growth (Chen et al. 2012, Silva et al. 2015), the results of total chlorophyll by the supply of $B$ in the control and high availability of micronutrients can be attributed to an eventual low nodulation and absorption of water and nutrients by the roots, which affects the assimilation of $\mathrm{N}$ - important component of the chlorophyll molecules (Prado 2008, Silva et al. 2015).

The variations in the effects for the chlorophyll content in the plants of soil fertilization treatments with varied doses of micronutrient (adopting B as reference) revealed that the supply of up to $4.0 \mathrm{~kg} \mathrm{ha}^{-1}$ of the micronutrient did not affect the chlorophyll index at 28 and 46 days after emergence (Flores et al. 2018a), the fertilization with 
$4.39 \mathrm{~kg} \mathrm{ha}^{-1}$ promoted a higher chlorophyll index at 40 days after germination (Flores et al. 2017), while doses up $6.0 \mathrm{~kg} \mathrm{ha}^{-1}$ reduced pigment rates in common bean leaves (Flores et al. 2018b).

Atmospheric $\mathrm{CO}_{2}$ must diffuse through the stomatal opening to the carboxylation sites inside the plant cells for photosynthesis occur, where $C i$ is lower as a function of $A$ and $g s$ rates (Aalto and Juurola 2002). In this aspect, the evaluation of the physiological performance of the soybean showed that the control treatment produced a lower $A$, whereas $\mathrm{gs}$ and $\mathrm{Ci}$ were more effective, revealing an inverse effect to that observed in the treatment with high availability of micronutrients (Table 5). Investigating such physiological parameters, Warren (2004) observed that the positive response of photosynthesis to nutrient supply was not accompanied by changes in gs and $\mathrm{Ci}$. In the work of Flores et al. (2018a), increasing doses of micronutrients (sources with wide-ranging solubilities) applied to the soil also did not affect $\mathrm{Ci}$ and gs; however, in different soils, the application of $\mathrm{Zn}, \mathrm{Cu}$ and $\mathrm{B}$ at different levels improved $A$, gs, total chlorophyll and fruit production (llyas et al. 2015). It should be noted that in the present study grain yield per plant (MGP) was not affected by treatments (Table 7), a fact similar to that observed by Mallarino et al. (2013).

The soil used in this study present the initial contents of Mn classified as low and high $\mathrm{Zn}$ as high, by Ribeiro et al. (1999) interpretation (Table 1), the concentrations of these micronutrients supplied in the treatments maintained a disparity in the levels of availability recommended by these authors as an ideal. For Barbosa et al. (2016), this reinforces the low efficiency of $\mathrm{Mn}$ fertilization in the soil compared to other micronutrients, requiring high doses to increase the absorption by plants. Our results demonstrated that not even the largest accumulation of leaf $\mathrm{Mn}(9.08$ $\mathrm{mg} \mathrm{kg}^{-1}$ biomass) supply this nutrient to the soybean crop, which is in the range between 20 and $200 \mathrm{mg} \mathrm{kg}^{-1}$ (Galrão 2004), being detected symptoms typical of Mn deficiency, such as necrosis and chlorosis internerval (Dechen and Nachtigall 2006). In this scenario, the Mn deficiency causes damages in the chloroplast structure due to a reduction in the levels of the enzyme MnSOD (Allen et al. 2007) and an increase in oxygen free radicals (Marschner 2012, Salvador et al. 2013), affecting photosynthesis rate and reducing the amount of chlorophyll, which decreases the level of soluble carbohydrates in plants (Ndakidemi et al. 2011), as observed for total chlorophyll, $A$ and dry weight of shoot (Tables 4 and 5).

The evaluation of the nutritional state of soybean plants also showed that fertilization with increasing doses of fertilizer applied to the soil reduced the absorption of $\mathrm{Zn}$ by the plants (Table 6), where only the control guaranteed enough leaf content, between 20 and $50 \mathrm{mg} \mathrm{kg}^{-1}$ (Galrão 2004). This behavior resembles that obtained by Barbosa et al. (2016), although they found an increase in the level of $Z n$ in the soil and a positive effect on soybean yield. For some authors, $\mathrm{Zn}$ homeostasis in plants is maintained mainly by the coordinated regulation of a wide network of homologous transporters in different plant species (Moreau et al. 2002, Ramesh et al. 2003, Vatansever et al. 2016b). In this sense, physiological and biochemical studies have demonstrated that the responsiveness of $\mathrm{Zn}$ is linked to the establishment of defense mechanisms, such as chelation (Bertrand and Poirier 2005, Solymosi and Bertrand 2010), presuming the effects observed by the excessive doses applied to the soil.

Allied to a series of genetic and environmental factors influencing the response of plants submitted to adverse soil fertility conditions (Gaspar et al. 2018), the nutritional demand for soybean is still hampered by the difference in micronutrient concentration with the doses supplied through a single source of slow release in the soil, such as oxides. This suggests that the benefits of these fertilizers in providing $\mathrm{B}, \mathrm{Cu}, \mathrm{Mn}$ and $\mathrm{Zn}$ need longer times than this research, or even requires foliar supplementation with sources of high solubility, especially for the care of $\mathrm{Mn}$ by the crop.

\section{Acknowledgements}

This study was financed in part by the Coordenação de Aperfeiçoamento de Pessoal de Nível Superior - Brasil (CAPES) - Finance Code 001"

\section{References}

Aalto T and Juurola E. 2002. A three-dimensional model of $\mathrm{CO}_{2}$ transport in airspaces and mesophyll cells of a silver birch leaf. Plant, Cell and Environment 25:1399-1409.

Adress M et al. 2015. The effect of excess copper on growth and physiology of important food crops: a review. Environmental Science and Pollution Research 22:8148-8162.

Allen MD et al. 2007. Manganese deficiency in Chlamydomonas results in loss of photosystem II and MnSOD function, sensitivity to peroxides, and secondary phosphorus and iron deficiency. Plant Physiology 143:263-277.

Ando $\mathrm{Y}$ et al. 2013. Copper in xylem and phloem saps from rice (Oryza sativa): the effect of moderate copper concentrations in the growth medium on the accumulation of five essential metals and a speciation analysis of copper-containing compounds. Functional Plant Biology 40:89-100.

Barbosa JM et al. 2016. Effects of micronutrients application on soybean yield. Australian Journal Crop Science 10:1092-1097.

Bertrand M and Poirier I. 2005. Photosynthetic organisms and excess of metals. Photosynthetica 43:345-353.

Burns HA. 2017. Soybean micronutrient content in irrigated plants grown in the Midsouth. Communications in Soil Science and Plant Analysis 48:808-817. 
Cakmak I and Römheld V. 1997. Boron deficiency-induced impairments of cellular functions in plants. Plant and Soil 193:71-83.

Carmo CAFS et al. 2000. Métodos de análise de tecidos vegetais utilizados na Embrapa Solos. Circular Técnica, 6. Rio de Janeiro: Embrapa Solos.

Chen LS et al. 2012. Boron stresses and tolerance in citrus. African Journal of Biotechnology 11:5961-5969.

Clemens S. 2001. Molecular mechanisms of plant metal tolerance and homeostasis. Planta 212:475-486.

Dechen AR and Nachtigall GR. 2006. Micronutrientes. In: Fernandes MS (ed). Nutrição Mineral de Plantas. Sociedade Brasileira de Ciência do Solo: Viçosa. pp.328-352.

Enderson JT et al. 2015. Soybean yield response to foliar-applied micronutrientes and relationships among soil and tissue tests. Agronomy Journal 107:2143-2161.

Ferreira DF. 2010. SISVAR (versão 5.6). Lavras, MG: DEX/UFLA.

Flores RA et al. 2017. Nutrition and production of Phaseolus vulgaris (BRS Estilo) following boron application on soil. Communications in Soil Science and Plant Analysis 48:1409-1416.

Flores RA et al. 2018a. Grain yield of Phaseolus vulgaris in a function of application of boron in soil. Journal of Soil Science and Plant Nutrition 18:144-156.

Flores RA et al. 2018b. Common bean productivity following diverse boron applications on soil. Communications in Soil Science and Plant Analysis 49:725-734.

Galrão EZ. 2004. Micronutrientes. In: Sousa DMG and Lobato E (Eds). Cerrado: correção do solo e adubação. Embrapa Cerrados: Planaltina. pp.185-226.

Gaspar AP et al. 2018. Secondary and micronutrient uptake, partitioning, and removal across a wide range of soybean seed yield levels. Agronomy Journal 110:1328-1338.

Hänsch R and Mendel RR. 2009. Physiological functions of mineral micronutrients ( $\mathrm{Cu}, \mathrm{Zn}, \mathrm{Mn}, \mathrm{Fe}, \mathrm{Ni}, \mathrm{Mo}, \mathrm{B}, \mathrm{Cl})$. Current Opinion in Plant Biology 12:259-266.

llyas A et al. 2015. Effect of micronutrients ( $\mathrm{Zn}, \mathrm{Cu}$ and B) on photosynthetic and fruit yield attributes of citrus reticulata blanco var. kinnow. Pakistan Journal of Botany 47:1241-1247.

Mallarino AP et al. 2013. Corn and soybean response to the micronutrients boron, manganese, and zinc applied to the soil. lowa State Research Farm Progress Reports. Paper 2084. Available at: http://lib.dr.iastate.edu/farms_reports/2084. Accessed on Nov. $20,2018$.

Mantovi $\mathrm{P}$ et al. 2003. Accumulation of copper and zinc from liquid manure in agricultural soils and crop plants. Plant and Soil 250:249-257.

Marschner H. 2012. Mineral nutrition of higher plants. Elsevier: London.

Moreau S et al. 2002. GmZIP1 encodes a symbiosis-specific zinc transporter in soybean. Journal of Biological Chemistry 15:4738-4746.

Ndakidemi PA et al. 2011. Micronutrient uptake in common bean (Phaseolus vulgaris L.) as affected by rhizobium inoculation, and the supply of molybdenum and lime. Journal of Plant Biology and Omics 4:40-52.

Prado RM. 2008. Nutrição de Plantas. Editora UNESP: Jaboticabal.

Ramesh SA et al. 2003. Differential metal selectivity and gene expression of two zinc transporters from rice. Plant Physiology 133:126-134.

Ribeiro AC et al. 1999. Recomendações para o uso de corretivos e fertilizantes em Minas Gerais: 5ª aproximação. Comissão de Fertilidade do Solo do Estado de Minas Gerais: Viçosa.

Richetti A and Garcia RA. 2017. Viabilidade econômica da cultura da soja para a safra 2017/2018, em Mato Grosso do Sul. EMBRAPA: Comunicado Técnico.

Salvador VH et al. 2013. Cinnamic acid increases lignin production and inhibits soybean root growth. PLoS ONE 8:69105.

Santos HG et al. 2013a. Sistema brasileiro de classificação de solos. Embrapa: Brasília.

Santos EF et al. 2013b. Photosynthesis rate, chlorophyll content and initial development of physic nut without micronutrient fertilization. Revista Brasileira de Ciência do Solo 37:1334-1342.

SEPLAN - Secretaria do Planejamento e da Modernização da Gestão Pública -. Superintendência de Pesquisa e Zoneamento EcológicoEconômico. Diretoria de Zoneamento Ecológico-Econômico. 2012. Atlas do Tocantins: subsídios ao Planejamento da Gestão Territorial. Seplan: Palmas.

Silva MR et al. 2015. Adubação bórica na produção de forragem e componentes radiculares de trevo branco. Bioscience Journal 31:65-72. Solymosi K and Bertrand M. 2010. Soil metals, chloroplasts, and secure crop production: a review. Agronomy for Sustainable Environment 31:245-272.

Tavallali V. 2017. Interactive effects of zinc and boron on growth, photosynthesis, and water relations in pistachio. Journal of Plant Nutrition 40:1588-1603.

Urano EOM et al. 2007. Determinação de teores ótimos de nutrientes em soja pelos métodos chance matemática, sistema integrado de diagnose e recomendação e diagnose da composição nutricional. Revista Brasileira de Ciência do Solo 31:63-72.

Vatansever R et al. 2016a. Essential and beneficial trace elements in plants, and their transport in roots: a review. Applied Biochemistry and Biotechnology 181:464-482.

Vatansever $\mathrm{R}$ et al. 2016b. Comparative and phylogenetic analysis of zinc (Zn) transporter genes/proteins in plants. Turkish Journal of Biology 40:600-601.

Wang $\mathrm{H}$ et al. 2009. Effects of zinc and soil moisture on photosynthetic rate and chlorophyll fluorescence parameters of maize. Biologia Plantarum 53:191-194.

Warren CR. 2004. The photosynthetic limitation posed by internal conductance to $\mathrm{CO}_{2}$ movement is increased by nutrient supply. Journal of Experimental Botany 55:2313-2321. 